\title{
Influence of Palm Oil Fuel Ash and W/B Ratios on Compressive Strength, Water Permeability, and Chloride Resistance of Concrete
}

\author{
Wachilakorn Sanawung, ${ }^{1}$ Tieng Cheewaket, ${ }^{2}$ \\ Weerachart Tangchirapat, ${ }^{1}$ and Chai Jaturapitakkul ${ }^{1}$ \\ ${ }^{1}$ Department of Civil Engineering, Faculty of Engineering, King Mongkut's University of Technology Thonburi, Bang Mod, \\ Thung Khru, Bangkok 10140, Thailand \\ ${ }^{2}$ Department of Civil Engineering, Faculty of Engineering, Burapha University, Chonburi 20131, Thailand
}

Correspondence should be addressed to Weerachart Tangchirapat; weerachart.tan@kmutt.ac.th

Received 20 March 2017; Accepted 23 May 2017; Published 4 July 2017

Academic Editor: Tung-Chai Ling

Copyright (C) 2017 Wachilakorn Sanawung et al. This is an open access article distributed under the Creative Commons Attribution License, which permits unrestricted use, distribution, and reproduction in any medium, provided the original work is properly cited.

\begin{abstract}
This research studies the effects of W/B ratios and palm oil fuel ash (POFA) on compressive strength, water permeability, and chloride resistance of concrete. POFA was ground until the particles retained on sieve number 325 were less than $5 \%$ by weight. POFA was used to partially replace OPC at rates of 15,25 , and $35 \%$ by weight of binder. The water to binder (W/B) ratios of concrete were 0.40 and 0.50 . The compressive strength, water permeability, and chloride resistance of concrete were investigated up to 90 days. The results showed that POFA concrete with W/B ratio of 0.40 had the compressive strengths ranging from 45.8 to $55.9 \mathrm{MPa}$ or $82-94 \%$ of OPC concrete at 90 days, while POFA concrete with W/B ratio of 0.50 had the compressive strengths of $33.9-41.9 \mathrm{MPa}$ or $81-94 \%$ of OPC concrete. Furthermore, the compressive strength of concrete incorporation of ground POFA at $15 \%$ was the same as OPC concrete. The water permeability coefficient and the chloride ion penetration of POFA concrete were lower than OPC concrete when both types of concrete had the same compressive strengths. The findings also indicated that water permeability and chloride ion penetration of POFA concrete were significantly reduced compared to OPC concrete.
\end{abstract}

\section{Introduction}

Palm oil fuel ash (POFA) is a by-product from biomass power plants, in which palm oil residues such as fibers, shells, and empty fruit bunches are burned to generate electricity. In 2013, approximately 6.25 million tons of palm oil residues were produced in Thailand. After combustion, approximately 312,500 tons of POFA were obtained or approximately $5 \%$ by weight of palm oil residue [1]. Since the palm oil is the main material in the production of biodiesel, the by-product of palm oil fuel ash is tended to increase annually, whereas the application of POFA remains to be very limited. Thus, most POFA is disposed as waste in landfills, which causes many environmental problems. The main chemical composition of palm oil fuel ash is silicon dioxide $\left(\mathrm{SiO}_{2}\right)$, and previous studies have shown that POFA in its original size is not suitable as a good pozzolan due to its large particle and high porosity [1]. However, high fineness POFA is a good pozzolanic material. Therefore, the POFA should be ground to higher fineness before it is used to partially replace OPC in concrete [2-4].

Previous researchers have reported that blast furnace slag or pozzolans such as fly ash, silica fume, rice husk ash, and bagasse ash can be used to partially replace OPC in concrete mixture [5-10]. POFA has been introduced as a pozzolanic material in concrete and most studies of POFA have focused on the mechanical properties of concrete such as compressive strength and modulus of elasticity of concrete [1-4]. Moreover, POFA has been used to replace cement as a binder in the geopolymer mortar and concrete to improve the compressive strength [11-13]. Some studies have considered the durability of concrete in terms of chloride 
TABLE 1: Physical properties of the materials.

\begin{tabular}{lccc}
\hline Sample & Specific gravity & Retained on a $45 \mu \mathrm{m}$ sieve (number 325) $(\%)$ & Median particle size, $d_{50}(\mu \mathrm{m})$ \\
\hline Type I Portland cement & 3.14 & 13.5 & 14.7 \\
POFA (before grinding) & 1.89 & 94.4 & 183.0 \\
Ground POFA & 2.52 & 1.7 & 10.7 \\
\hline
\end{tabular}

TABle 2: Chemical compositions of the ground POFA and Type I Portland cement.

\begin{tabular}{lccccccccc}
\hline Sample & $\mathrm{SiO}_{2}$ & $\mathrm{Al}_{2} \mathrm{O}_{3}$ & $\mathrm{Fe}_{2} \mathrm{O}_{3}$ & $\mathrm{CaO}$ & $\mathrm{MgO}$ & $\mathrm{K}_{2} \mathrm{O}$ & $\mathrm{Na}_{2} \mathrm{O}$ & $\mathrm{SO}_{3}$ & $\mathrm{LOI}$ \\
\hline Cement & 20.9 & 4.8 & 3.8 & 65.4 & 1.2 & 0.4 & 0.2 & 2.7 & 1.0 \\
Ground POFA & 55.4 & 9.1 & 5.5 & 12.4 & 4.6 & - & - & 2.3 & 7.9 \\
\hline
\end{tabular}

TABLE 3: Mixture proportions of the types of concrete.

\begin{tabular}{|c|c|c|c|c|c|c|c|}
\hline \multirow{2}{*}{ Sample } & \multicolumn{6}{|c|}{ Mix proportion $\left(\mathrm{kg} / \mathrm{m}^{3}\right)$} & \multirow{2}{*}{ Slump (mm) } \\
\hline & Cement & Ground POFA & Sand & Crushed limestone & Effective water & Super P. & \\
\hline $40 \mathrm{CT}$ & 475 & 0 & 765 & 935 & 190 & 2.38 & 85 \\
\hline $40 \mathrm{P} 15$ & 404 & 71 & 765 & 910 & 190 & 2.85 & 72 \\
\hline $40 \mathrm{P} 25$ & 357 & 118 & 765 & 895 & 190 & 3.09 & 80 \\
\hline $40 \mathrm{P} 35$ & 309 & 166 & 765 & 875 & 190 & 3.33 & 75 \\
\hline $50 \mathrm{CT}$ & 385 & 0 & 765 & 1012 & 190 & 0.39 & 90 \\
\hline $50 \mathrm{P} 15$ & 327 & 58 & 765 & 990 & 190 & 0.58 & 85 \\
\hline $50 \mathrm{P} 25$ & 289 & 96 & 765 & 980 & 190 & 0.77 & 75 \\
\hline 50P35 & 250 & 135 & 765 & 965 & 190 & 1.16 & 80 \\
\hline
\end{tabular}

ion penetration $[14,15]$ and corrosion resistance of highstrength, high workability concrete [16]. Once chloride ions penetrate into concrete and their concentrations around the reinforcing steel exceed a critical level, they will break down the protective film, which leads to the beginning of steel corrosion.

However, few studies have jointly considered the three main properties for durability in concrete, that is, compressive strength, water permeability, and chloride ion penetration. Moreover, POFA concrete with different $\mathrm{W} / \mathrm{B}$ ratios was also considered in this study. In addition, the results obtained from this study would be beneficial to understand the POFA concrete's properties and to apply POFA concrete in the future.

\section{Experimental Programs}

2.1. Materials. Palm oil fuel ash (POFA) used in this study was collected from a power plant in Thailand. The POFA obtained from the power plant was in a dry condition and had a low pozzolanic reaction due to its large particle sizes and high porosity; therefore, it was ground with a ball mill to improve its reactivity. The POFA was ground by ball mill to a required level of fineness until the retained particles were on a number 325 sieve of $1.7 \%$ by weight.

Ordinary Portland cement (OPC), natural river sand with a fineness modulus of 3.09, crushed limestone with a maximum size of $19 \mathrm{~mm}$, and a type-F superplasticizer (SP) were used in this study. The physical properties of the OPC and POFA are shown in Table 1.

As shown in Table 2, the chemical compositions indicate that the sums of $\mathrm{SiO}_{2}, \mathrm{Fe}_{2} \mathrm{O}_{3}$, and $\mathrm{Al}_{2} \mathrm{O}_{3}$ in the ground POFA were $70 \%(55.4+9.1+5.5)$ by weight, whereas the values of LOI and $\mathrm{SO}_{3}$ were 7.9 and $2.3 \%$, respectively. Awal and Hussin [17] found that the sum of $\mathrm{SiO}_{2}, \mathrm{Fe}_{2} \mathrm{O}_{3}$, and $\mathrm{Al}_{2} \mathrm{O}_{3}$ in POFA from Malaysia was $59.7 \%$ and the values of LOI and $\mathrm{SO}_{3}$ were 18.0 and $2.8 \%$, respectively, which were not much different from the results of this study (except LOI).

2.2. Mix Proportions of Concrete. To investigate the effects of $\mathrm{W} / \mathrm{B}$ ratios on properties of concrete containing ground POFA, two values of $\mathrm{W} / \mathrm{B}$ ratio were used. The concrete was designed to have binder contents of 475 and $385 \mathrm{~kg} / \mathrm{m}^{3}$, corresponding to the $\mathrm{W} / \mathrm{B}$ ratios of 0.40 and 0.50 , respectively. The mixture proportions of the control types of concrete (40CT and 50CT) and the types of concrete containing ground POFA (40P15, 40P25, 40P35, 50P15, 50P25, and 50P35) are summarized in Table 3. The compressive strengths of the 40CT and 50CT control types of concrete (types of concrete using OPC as a binder) were designed to be 50 and $40 \mathrm{MPa}$ at 28 days, respectively. A type-F superplasticizer was used to produce concrete having roughly the same slump between 50 and $100 \mathrm{~mm}$ which was the typical workability for general concrete. The cement replacements with ground POFA in the concrete mixtures were at rates of 15,25 , and $35 \%$ by weight of binder (ground POFA + OPC). The effects of W/B ratios 


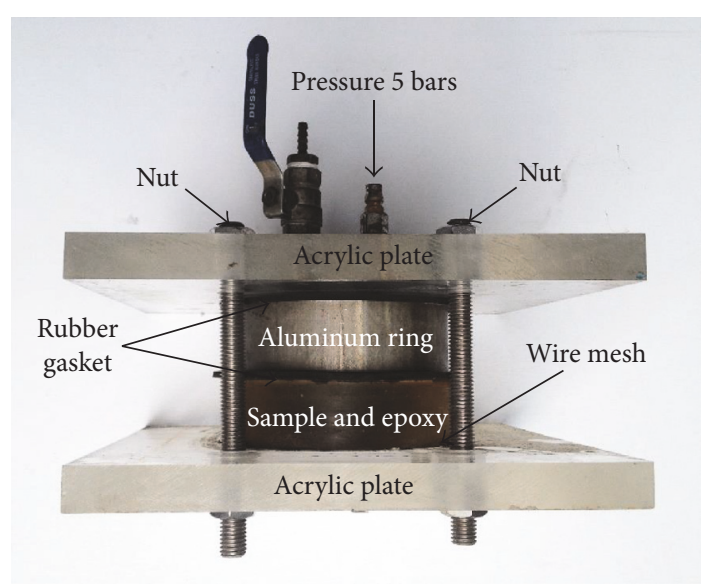

(a) Water permeability housing cell

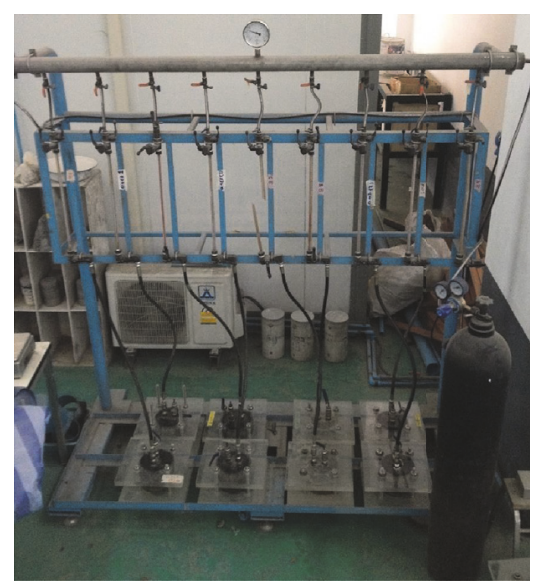

(b) Water permeability apparatus

FIGURE 1: Water permeability coefficient test.

and ground POFA on the properties of the concrete were investigated and compared to the control concrete.

\subsection{Tests for the Compressive Strengths of Concrete. Cylin-} drical concrete specimens with a diameter of $100 \mathrm{~mm}$ and a height of $200 \mathrm{~mm}$ were used to determine the compressive strengths. To prepare the concrete specimens, cylindrical molds were filled with fresh concrete in three equal layers, and each layer was rodded 25 times using a standard rod. After casting, the concrete specimens were allowed to set for $24 \mathrm{~h}$ before being removed from the molds and were cured in fresh water. The concrete specimens were tested for compressive strengths at 7, 28, 60, and 90 days according to ASTM C39 [18]. At each testing age, three samples were used to obtain an average value.

2.4. Tests for the Water Permeabilities of the Concrete. The steady flow method was applied to test the water permeability of the concrete. Each of the $100 \times 200 \mathrm{~mm}$ cylinder types of concrete at the middle was cut to have 2 sliced pieces of $100 \mathrm{~mm}$ in diameter and $40 \mathrm{~mm}$ in thickness. Epoxy resin with a thickness of $25 \mathrm{~mm}$ was coated around the perimeter of the sliced concrete specimen. The concrete sample, after the epoxy resin set for $24 \mathrm{~h}$, was installed in housing cells and a water permeability test apparatus, as shown in Figure 1, which was suggested by Chan and $\mathrm{Wu}$ [19]. The test of water permeability of concrete followed the procedure used by Tangchirapat et al. [20]. The concrete was conducted to determine water permeability coefficient (WPC) at the ages of 28 and 90 days. The water permeability coefficient of concrete was calculated from the following equation [21]:

$$
K=\frac{\rho L g Q}{P A} .
$$

$K$ is the water permeability coefficient, WPC, $(\mathrm{m} / \mathrm{s}) ; \rho$ is the density of water $\left(\mathrm{kg} / \mathrm{m}^{3}\right) ; g$ is the acceleration due to gravity, $9.81\left(\mathrm{~m} / \mathrm{s}^{2}\right) ; Q$ is the constant flow rate $\left(\mathrm{m}^{3} / \mathrm{s}\right) ; L$ is the length of the concrete sample $(\mathrm{m}) ; P$ is the water pressure
( $0.5 \mathrm{MPa})$; and $A$ is the cross-sectional area of the concrete sample $\left(\mathrm{m}^{2}\right)$.

2.5. Tests for the Electrical Indication of the Concrete's Ability to Resist Chloride Ion Penetration. At ages of 28 and 90 days, a $100 \mathrm{~mm}$ diameter and $50 \mathrm{~mm}$ height concrete specimen was cut from a $100 \times 200 \mathrm{~mm}$ concrete cylinder, coated with epoxy resin, and tested for rapid chloride ion penetration in accordance with ASTM C1202 [22]. This test method covers the determination of the electrical conductance of concrete to provide a rapid indication of its resistance to the penetration of chloride ions. The total passed charge (in coulombs) was recorded by application of a $60 \mathrm{~V}$ voltage (DC) across the specimen during a $6 \mathrm{~h}$ period. The set-up for the rapid chloride ion penetration test apparatus is shown in Figure 2.

\section{Results and Discussion}

3.1. Compressive Strength of Concrete. Figure 3 shows the compressive strengths of the control concrete and the POFA concrete with OPC replacements of 15,25 , and $35 \%$ by weight of binder. The development of the compressive strengths of the POFA concrete was compared to that of the 40CT and 50CT types of concrete, from which the effects of the different $\mathrm{W} / \mathrm{B}$ ratios on the compressive strengths and durability properties of the concrete were investigated.

The 40CT and 50CT types of concrete gained compressive strengths of 45.5 and $31.5 \mathrm{MPa}$ at 7 days, respectively. At 28, 60 , and 90 days, the 40CT concrete developed strengths up to $50.2,54.1$, and $55.9 \mathrm{MPa}$, respectively, whereas the 50CT concrete developed lesser strengths, which were 39.6, 41.4, and 41.9 $\mathrm{MPa}$, respectively. At the same $\mathrm{W} / \mathrm{B}$ ratios, the POFA concrete produced lower compressive strengths than those of the control concrete up to 90 days. At 7 days, the $40 \mathrm{P} 15$ concrete had compressive strength of $38.9 \mathrm{MPa}$ and increased to $46.2 \mathrm{MPa}$ at 28 days. At the later ages of 60 and 90 days, the 40P15 concrete had compressive strengths of 49.1 and $52.8 \mathrm{MPa}$, respectively. The compressive strengths of the 


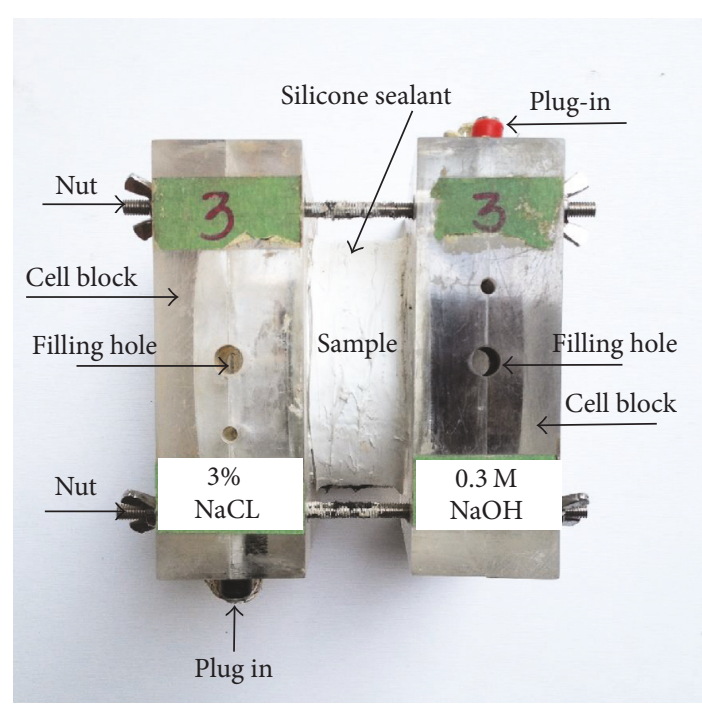

(a) Chloride ion penetration housing cell

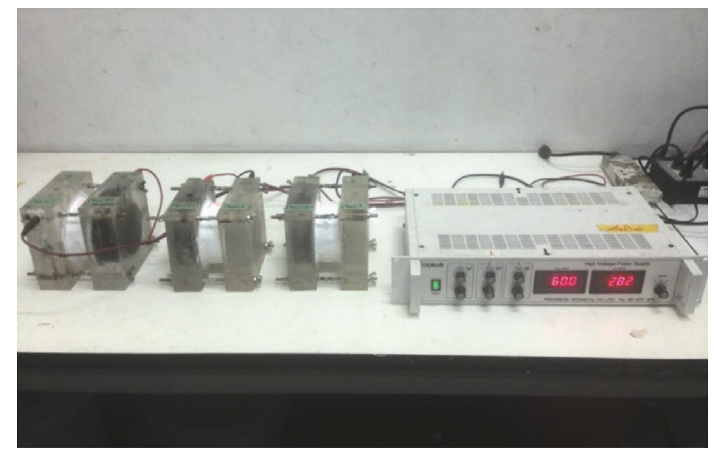

(b) Chloride ion penetration apparatus

FIGURE 2: Installation test for the electrical indication of a concrete's ability to resist chloride ion penetration.

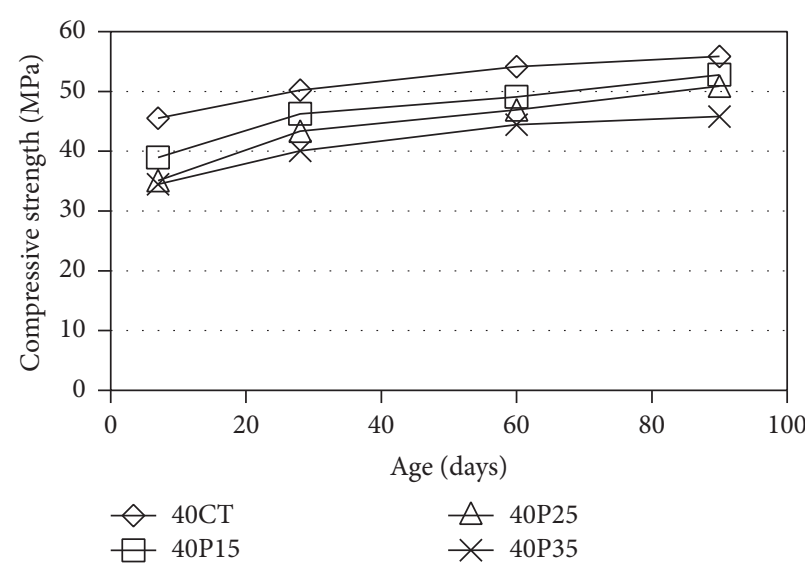

(a) $\mathrm{W} / \mathrm{B}$ ratio of 0.40



(b) W/B ratio of 0.50

FIGURE 3: Compressive strengths of the concrete at different ages.

40P25 concrete were 35.1, 43.3, 46.9, and 50.9 MPa at 7, 28, 60, and 90 days, respectively. At ages of 7, 28, 60, and 90 days, the $40 \mathrm{P} 35$ concrete had compressive strengths of $34.5,40.0,44.4$, and $45.8 \mathrm{MPa}$, respectively.

The results indicated that the use of ground POFA to replace OPC at rates of 15 to $35 \%$ by weight of binder slightly decreased the compressive strength of the concrete. The $40 \mathrm{P} 15$ concrete had a compressive strength of $92 \%$ of the $40 \mathrm{CT}$ concrete at 28 days and developed to $94 \%$ of the $40 \mathrm{CT}$ concrete at 90 days, whereas the $50 \mathrm{P} 15$ concrete had a compressive strength of $92 \%$ of the 50CT concrete at 28 days and developed to $94 \%$ of the $50 \mathrm{CT}$ concrete at 90 days. When the ground POFA was used to replace OPC in concrete, it resulted in a decrease in the compressive strength, and the results conformed to those of Sata et al. [23]. The decrease in the compressive strengths of the POFA concrete could be attributed to the lower quantity of OPC, such that the compressive strength obtained from the pozzolanic reaction of the ground POFA was not high enough to compensate for the loss in strength due to the hydration of the cement. However, the use of ground POFA to replace OPC can reduce the usage of OPC in concrete mixtures and the compressive strength is not much different from the control concrete at the same $\mathrm{W} / \mathrm{B}$ ratio.

3.2. Water Permeability. Table 4 shows the water permeability coefficients (WPCs) and the compressive strengths of concrete at 28 and 90 days. The ratio of WPC $(k / k$ control) is the normalized WPC of POFA concrete as compared with the control concrete at the same testing age and $\mathrm{W} / \mathrm{B}$ ratio $(40 \mathrm{CT}$ or 50CT concrete). The 40CT and 50CT types of concrete at 28 days had the WPC of $3.01 \times 10^{-13}$ and $4.81 \times 10^{-13} \mathrm{~m} / \mathrm{s}$ and reduced to $1.96 \times 10^{-13}$ and $3.2 \times 10^{-13} \mathrm{~m} / \mathrm{s}$ at 90 days, respectively, which was similar to the previous research [24] 
TABLE 4: Compressive strengths and water permeability coefficients of the types of concrete at 28 and 90 days.

\begin{tabular}{lcccc}
\hline \multirow{2}{*}{ Mix } & \multicolumn{2}{c}{ Compressive strength $(\mathrm{MPa})$-normalized $(\%)$} & Water permeability $(k) \times 10^{-13}, k(\mathrm{~m} / \mathrm{s})-k / k$ control \\
& 28 days & 90 days & 28 days & 90 days \\
\hline $40 \mathrm{CT}$ & $50.2-(100)$ & $55.9-(100)$ & $3.01-1.00$ & $1.96-1.00$ \\
$40 \mathrm{P} 15$ & $46.2-(92)$ & $52.8-(94)$ & $2.26-0.75$ & $1.08-0.53$ \\
$40 \mathrm{P} 25$ & $43.3-(86)$ & $50.9-(91)$ & $3.33-1.11$ & $2.04-1.04$ \\
$40 \mathrm{P} 35$ & $40.0-(80)$ & $45.8-(82)$ & $4.52-1.50$ & $2.86-1.46$ \\
\hline $50 \mathrm{CT}$ & $39.6-(100)$ & $41.9-(100)$ & $4.81-1.00$ & $3.20-1.00$ \\
$50 \mathrm{P} 15$ & $36.4-(92)$ & $39.5-(94)$ & $5.06-1.05$ & $2.91-0.91$ \\
$50 \mathrm{P} 25$ & $34.6-(88)$ & $35.5-(85)$ & $6.67-1.39$ & $3.86-1.21$ \\
$50 \mathrm{P} 35$ & $31.7-(80)$ & $33.9-(81)$ & $7.03-1.46$ & $4.51-1.41$ \\
\hline
\end{tabular}

demonstrating that the WPCs of cement concrete were between $10.00 \times 10^{-13}$ and $1.00 \times 10^{-13} \mathrm{~m} / \mathrm{s}$ at 28 days.

This study showed that the WPCs of the POFA concrete decreased as the curing age increased. For example, at 28 and 90 days, the $40 \mathrm{P} 15$ concrete had the WPCs of $2.26 \times 10^{-13}$ and $1.08 \times 10^{-13} \mathrm{~m} / \mathrm{s}$ or 0.75 and 0.53 of the $40 \mathrm{CT}$ concrete at 28 and 90 days, respectively, which were lower than those of the control concrete. It should be noted that the $40 \mathrm{P} 15$ concrete had a lower compressive strength than that of the $40 \mathrm{CT}$ concrete and still had a lower WPC than the 40CT concrete too.

The POFA concrete with $15 \%$ cement replacement had the WPCs lower than those of the control concrete and had higher WPCs than those of the control concrete at replacement rates of 25 and $35 \%$. For example, at 28 days, the 40P25 and 40P35 types of concrete had the WPCs of 3.33 $\times 10^{-13}$ and $4.52 \times 10^{-13} \mathrm{~m} / \mathrm{s}$ or 1.11 and 1.50 of the $40 \mathrm{CT}$ concrete, respectively. The WPCs of the concrete with W/B ratios of 0.40 at 90 days were slightly lower than those at 28 days. The WPCs of the 40P25 and 40P35 types of concrete were $2.04 \times 10^{-13}$ and $2.86 \times 10^{-13} \mathrm{~m} / \mathrm{s}$ or 1.04 and 1.46 of the $40 \mathrm{CT}$ concrete at 90 days, respectively. It should be noted that the compressive strengths of the 40P25 and 40P35 types of concrete at 90 days were 91 and $82 \%$ of the 40CT concrete, respectively.

The WPC ratios of the 50P15, 50P25, and 50P35 types of concrete at 90 days were $0.91,1.21$, and 1.41 of the 50CT concrete, respectively. At 90 days, the WPC ratios of the POFA concrete were slightly lower than the values at 28 days. This denotes that the WPCs of the POFA concrete at 25 and $35 \%$ OPC replacement were slightly higher than those of the control concrete. However, the POFA concrete at 15\% OPC replacement can produce concrete with lower WPC than that of the control concrete.

Considering the types of concrete with the same ranges of WPCs, it was found that the concrete with lower W/B ratio can replace OPC with ground POFA at a higher rate. For example, at 90 days, the WPCs of the 40P35 and 50P15 types of concrete were $2.86 \times 10^{-13} \mathrm{~m} / \mathrm{s}$ and $2.91 \times 10^{-13} \mathrm{~m} / \mathrm{s}$, respectively, but the $40 \mathrm{P} 35$ concrete had a ground POFA replacement of $35 \%$ by weight of binder. Note that the $40 \mathrm{P} 35$ and 50P15 types of concrete had compressive strengths of 45.8 and $39.5 \mathrm{MPa}$, respectively.
Considering the same ranges of compressive strengths but for types of concrete of different ages, the 40P35 and 50P15 types of concrete had compressive strengths of $40.0 \mathrm{MPa}$ at 28 days and $39.5 \mathrm{MPa}$ at 90 days, respectively. It was found that the $50 \mathrm{P} 15$ concrete had a WPC of $2.91 \times 10^{-13} \mathrm{~m} / \mathrm{s}$, whereas that of the $40 \mathrm{P} 35$ concrete was $4.52 \times 10^{-13} \mathrm{~m} / \mathrm{s}$. This suggested that the age of concrete has more influence on reducing water permeability compared to the compressive strength.

Table 4 also indicates that the increase in the compressive strength of POFA concrete could be attributed to the lower WPC. This is due to the incorporation of ground POFA, which made the concrete denser by pozzolanic reaction and packing effect was an effective way to reduce the water permeability of the POFA concrete. However, the WPCs of POFA concrete tended to increase as the POFA replacement increased to same extent, that is, 25 or $35 \%$ replacement. This result agreed with that of Chindaprasirt et al. [25] who reported that the water permeability of concrete containing pozzolans such as fly ash and rice husk-bark ash tended to increase as the fly ash and rice husk-bark ash replacement increased.

3.3. Chloride Ion Penetration. The results of the chloride ion penetration of concrete determined by ASTM C1202 [22] are given in Figure 4. At the same $\mathrm{W} / \mathrm{B}$ ratios, the total passed charges (coulombs) for the control concrete were much higher than those of the POFA concrete. The 40CT and $50 \mathrm{CT}$ types of concrete (W/B ratios of 0.40 and 0.50 ) had total passed charges of 3236 and 4507 coulombs at 28 days and reduced to 1891 and 3590 coulombs at 90 days, respectively. From the obtained results, the total passed charges for the control concrete decreased as the curing age increased and decreased as the $\mathrm{W} / \mathrm{B}$ ratio decreased.

Figure 4 also suggests that, at the age of 28 days, the control concrete with $\mathrm{W} / \mathrm{B}$ ratios of 0.40 and 0.50 can be classified as moderate and high for chloride ion penetration as specified by ASTM C1202 [22] because the values of the total passed charges of the 40CT and 50CT types of concrete were greater than 2000 and 4000 coulombs, respectively. However, at 90 days, the 40CT and 50CT types of concrete were classified as low and moderate for chloride ion penetration because the 


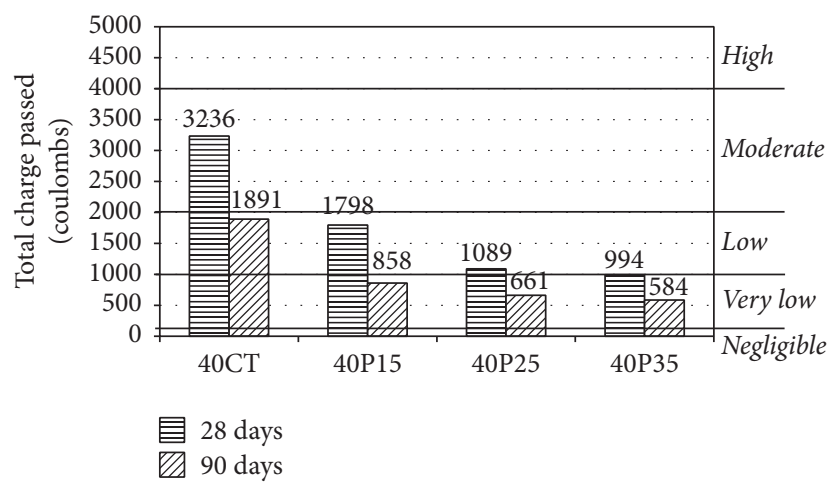

(a) $\mathrm{W} / \mathrm{B}=0.40$

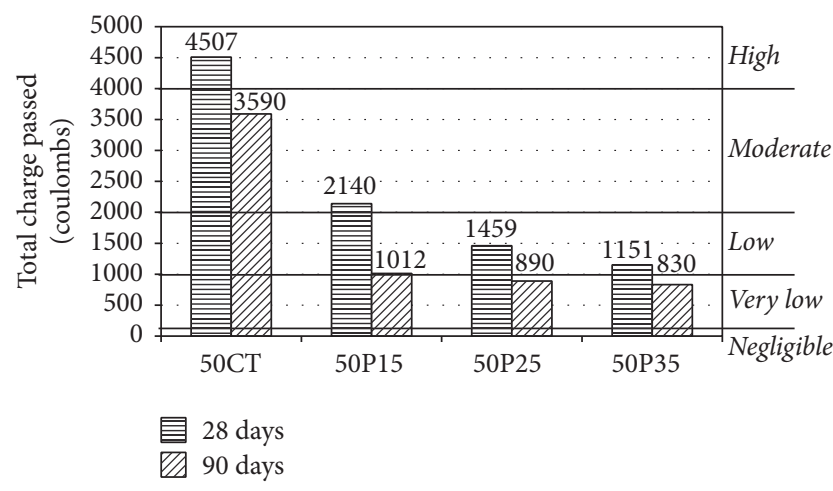

(b) $\mathrm{W} / \mathrm{B}=0.50$

FIgURE 4: Chloride ion penetration and the replacement of ground POFA in concrete for W/B ratios of 0.40 and 0.50.

TABLE 5: Compressive strengths and chloride ion penetrations of the types of concrete.

\begin{tabular}{lcccc}
\hline \multirow{2}{*}{ Mix } & \multicolumn{2}{c}{ Compressive strength (MPa)-normalized (\%) } & Total charge passed (coulombs)-normalized (\%) \\
& 28 days & 90 days & 28 days & 90 days \\
\hline 40 CT & $50.2-(100)$ & $55.9-(100)$ & $3236-100$ & $1891-100$ \\
40 P15 & $46.2-(92)$ & $52.8-(94)$ & $1798-56$ & $823-44$ \\
40 P25 & $43.3-(86)$ & $50.9-(91)$ & $1089-34$ & $661-35$ \\
40 P35 & $40.0-(80)$ & $45.8-(82)$ & $994-31$ & $584-31$ \\
\hline $50 \mathrm{CT}$ & $39.6-(100)$ & $41.9-(100)$ & $4507-100$ & $3590-100$ \\
50 P15 & $36.4-(92)$ & $39.5-(94)$ & $2140-47$ & $1012-28$ \\
$50 \mathrm{P} 25$ & $34.6-(88)$ & $35.5-(85)$ & $1459-32$ & $890-25$ \\
50 P35 & $31.7-(80)$ & $33.9-(81)$ & $1151-26$ & $830-23$ \\
\hline
\end{tabular}

values of the total passed charges were less than 2000 and 4000 coulombs, respectively.

For the POFA concrete, the values of total passed charges for the 50P15, 50P25, and 50P35 types of concrete were 2140, 1459 , and 1151 coulombs at 28 days and declined to 1012, 890, and 830 coulombs at 90 days, respectively. For the 40P15, $40 \mathrm{P} 25$, and 40P35 types of concrete, the values were only 1798 , 1089 , and 994 coulombs at 28 days and declined to 858, 661, and 584 coulombs at 90 days, respectively. It should be noted that the values of total passed charges of the POFA concrete at 28 days were classified as low for chloride ion penetration because the value of total passed charges was less than 2000 coulombs, except for the 50P15 concrete, which had total passed charges of 2140 coulombs. When the age of the POFA concrete reached 90 days, all the POFA concrete could be classified as very low for chloride ion penetration because the total passed charges were approximately 1000 coulombs or less. The results suggested that ground POFA could be used very effectively to reduce chloride ion penetration in concrete.

Table 5 shows the compressive strength and chloride ion penetration results of the types of concrete. The results suggested that the chloride ion penetration of the POFA concrete tended to decrease as the replacement of ground POFA and curing age increased. Use of ground POFA is effective in reducing chloride ion penetration in concrete, which is the same as the result of using fly ash and silica fume in concrete [26]. This improvement in concrete resistivity was due to the pozzolanic reaction, which improved the interfacial bonding between the aggregates and pastes [27, 28], resulting in impermeable and dense concrete [29].

The types of concrete with the same replacement of ground POFA, that is, the $25 \%$ replacement of OPC in the 40P25 and 50P25 types of concrete at 90 days, had the total passed charges of 661 and 890 coulombs, respectively. The 40P25 concrete had lower total passed charges because of its higher compressive strength and lower $\mathrm{W} / \mathrm{B}$ ratio and it was denser than the one with a higher $\mathrm{W} / \mathrm{B}$ ratio. These results have also been reported by many researchers [30, 31] who used fly ash or silica fume to replace OPC in concrete.

Considering the same ranges of compressive strengths but for POFA types of concrete with different $\mathrm{W} / \mathrm{B}$ ratios, that is, the $40 \mathrm{P} 35$ concrete and 50P15 concrete, which had the compressive strengths of $40.0 \mathrm{MPa}$ at 28 days and $39.5 \mathrm{MPa}$ at 90 days, respectively, it was found that the 40P35 and 50P15 types of concrete had the total passed charges of 994 and 1012 coulombs, respectively, which were approximately the same. Note that the total passed charges of the 40P35 concrete were considered at 28 days, whereas those of the 50P15 concrete were considered at 90 days.

Considering types of concrete cured at the same age and approximately the same total passed charges, the types of concrete to be considered are 40P15 and 50P35 at 90 days, which had total passed charges of 858 and 830 coulombs, 
respectively. The results suggested that the replacement with ground POFA at $35 \%$ in $50 \mathrm{P} 35$ yielded a compressive strength of $33.9 \mathrm{MPa}$ compared with that of $40 \mathrm{P} 15$ concrete (ground POFA of $15 \%$ ), which was $52.8 \mathrm{MPa}$, but both types of concrete had almost the same total passed charges. This means that the replacement of POFA was more effective to reduce the total passed charges compared to the increase in the compressive strength. When the replacement of ground POFA in the concrete increased, the chloride ion penetration of concrete tended to decrease. This was due to the higher pozzolanic reaction in 50P35, which reduced $\mathrm{Ca}(\mathrm{OH})_{2}$ content, produced more C-S-H gel [32], reduced porosity, and thus increased the resistance of the chloride ion penetration. The results conformed to a large amount of researches demonstrating that the increased replacement of blast furnace slag or pozzolan such as fly ash or silica fume in concrete can increase the resistance of chloride ion penetration when compared to types of concrete with lower replacement of pozzolan $[33,34]$.

\section{Conclusions}

The following can be concluded:

(1) The effects of $\mathrm{W} / \mathrm{B}$ ratios on the compressive strengths of the POFA concrete were similar to those of conventional concrete; that is, the compressive strength of POFA concrete increased as the $\mathrm{W} / \mathrm{B}$ ratio was decreased. Moreover, the POFA concrete (W/B ratios of 0.40 and 0.50 ) had approximately the same percentages of compressive strength compared to the control concrete with the same W/B ratios.

(2) The replacement of ground POFA in OPC at 15 and $35 \%$ by weight of binder had strengths of $94-80 \%$ of the control concrete at 28 and 90 days. In addition, the use of ground POFA in the concrete required slightly higher amounts of superplasticizer than those required by the control concrete.

(3) The replacement of ground POFA in OPC at $15 \%$ by weight of binder (40P15 and 50P15) produced good water permeability resistance results, although the compressive strengths of the POFA concrete were lower than those of the control concrete. In addition, the water permeability of the ground POFA concrete decreased as the compressive strength and curing age of the concrete increased.

(4) From the results of the rapid chloride ion penetration test, ground POFA can be used very effectively to reduce chloride ion penetration in concrete. Moreover, the replacement of ground POFA (15 to 35\%) is more important for increasing the chloride ion penetration resistance of concrete than for increasing its compressive strength.

\section{Conflicts of Interest}

The authors declare that they have no conflicts of interest.

\section{Acknowledgments}

The authors gratefully acknowledge the financial support from the Office of the Higher Education Commission, Thailand, under the National Research University (NRU) Project, King Mongkut's University of Technology Thonburi.

\section{References}

[1] W. Tangchirapat, T. Saeting, C. Jaturapitakkul, K. Kiattikomol, and A. Siripanichgorn, "Use of waste ash from palm oil industry in concrete," Waste Management, vol. 27, no. 1, pp. 81-88, 2007.

[2] A. S. M. Abdul Awal and I. A. Shehu, "Performance evaluation of concrete containing high volume palm oil fuel ash exposed to elevated temperature," Construction and Building Materials, vol. 76, pp. 214-220, 2015.

[3] J.-H. Tay, "Ash from oil-palm waste as concrete material," Journal of Materials in Civil Engineering, vol. 2, no. 2, pp. 94-105, 1990.

[4] J.-H. Tay and K.-Y. Show, "Use of ash derived from oil-palm waste incineration as a cement replacement material," Resources, Conservation and Recycling, vol. 13, no. 1, pp. 27-36, 1995.

[5] P. Chindaprasirt, C. Chotithanorm, H. T. Cao, and V. Sirivivatnanon, "Influence of fly ash fineness on the chloride penetration of concrete," Construction and Building Materials, vol. 21, no. 2, pp. 356-361, 2007.

[6] P. Chindaprasirt, S. Rukzon, and V. Sirivivatnanon, "Effect of carbon dioxide on chloride penetration and chloride ion diffusion coefficient of blended Portland cement mortar," Construction and Building Materials, vol. 22, no. 8, pp. 1701-1707, 2008.

[7] W. Deboucha, M. N. Oudjit, A. Bouzid, and L. Belagraa, "Effect of incorporating blast furnace slag and natural pozzolan on compressive strength and capillary water absorption of concrete," Procedia Engineering, vol. 108, pp. 254-261, 2015.

[8] W. Wongkeo, P. Thongsanitgarn, A. Ngamjarurojana, and A. Chaipanich, "Compressive strength and chloride resistance of self-compacting concrete containing high level fly ash and silica fume," Materials and Design, vol. 64, pp. 261-269, 2014.

[9] W. Tangchirapat, R. Buranasing, C. Jaturapitakkul, and P. Chindaprasirt, "Influence of rice husk-bark ash on mechanical properties of concrete containing high amount of recycled aggregates," Construction and Building Materials, vol. 22, no. 8, pp. 1812-1819, 2008.

[10] N. Chusilp, C. Jaturapitakkul, and K. Kiattikomol, "Utilization of bagasse ash as a pozzolanic material in concrete," Construction and Building Materials, vol. 23, no. 11, pp. 3352-3358, 2009.

[11] I. I. Bashar, U. J. Alengaram, M. Z. Jumaat, and A. Islam, "The effect of variation of molarity of alkali activator and fine aggregate content on the compressive strength of the fly ash: palm oil fuel ash based geopolymer mortar," Advances in Materials Science and Engineering, vol. 2014, Article ID 245473, 13 pages, 2014.

[12] T. O. Yusuf, M. Ismail, J. Usman, and A. H. Noruzman, "Impact of blending on strength distribution of ambient cured metakaolin and palm oil fuel ash based geopolymer mortar," Advances in Civil Engineering, vol. 2014, Article ID 658067, 8 pages, 2014.

[13] M. Y. J. Liu, C. P. Chua, U. J. Alengaram, and M. Z. Jumaat, "Utilization of palm oil fuel ash as binder in lightweight oil palm shell geopolymer concrete," Advances in Materials Science and Engineering, vol. 2014, Article ID 610274, 6 pages, 2014. 
[14] S. O. Bamaga, M. A. Ismail, and M. W. Hussin, "Chloride resistance of concrete containing palm oil fuel ash," Cement and Concrete Research, vol. 1, pp. 158-166, 2010.

[15] P. Chindaprasirt, S. Rukzon, and V. Sirivivatnanon, "Resistance to chloride penetration of blended Portland cement mortar containing palm oil fuel ash, rice husk ash and fly ash," Construction and Building Materials, vol. 22, no. 5, pp. 932-938, 2008.

[16] P. Chindaprasirt, C. Chotetanorm, and S. Rukzon, "Use of palm oil fuel ash to improve chloride and corrosion resistance of high-strength and high-workability concrete," Journal of Materials in Civil Engineering, vol. 23, no. 4, pp. 499-503, 2011.

[17] A. S. M. A. Awal and M. W. Hussin, "The effectiveness of palm oil fuel ash in preventing expansion due to alkali-silica reaction," Cement and Concrete Composites, vol. 19, no. 4, pp. 367-372, 1997.

[18] ASTM C39/C39M, "Standard test method for compressive strength of cylindrical concrete specimens, American Society for Testing and Materials, 2015".

[19] W. W. J. Chan and C. M. L. Wu, "Durability of concrete with high cement replacement," Cement and Concrete Research, vol. 30, no. 6, pp. 865-879, 2000.

[20] W. Tangchirapat, S. Khamklai, and C. Jaturapitakkul, "Use of ground palm oil fuel ash to improve strength, sulfate resistance, and water permeability of concrete containing high amount of recycled concrete aggregates," Materials \& Design, vol. 41, pp. 150-157, 2012.

[21] R. P. Khatri and V. Sirivivatnanon, "Methods for the determination of water permeability of concrete," ACI Materials Journal, vol. 94, no. 3, pp. 257-261, 1997.

[22] ASTM C1202-12, Standard test method for electrical indication of concrete's ability to resist chloride ion penetration. American Society for Testing and Materials, 2012.

[23] V. Sata, C. Jaturapitakkul, and K. Kiattikomol, "Utilization of palm oil fuel ash in high-strength concrete," Journal of Materials in Civil Engineering, vol. 16, no. 6, pp. 623-628, 2004.

[24] L. Zongjin and C. C. Kong, "New water permeability test scheme for concrete," ACI Materials Journal, vol. 97, no. 1, pp. 84-90, 2000.

[25] P. Chindaprasirt, S. Homwuttiwong, and C. Jaturapitakkul, "Strength and water permeability of concrete containing palm oil fuel ash and rice husk-bark ash," Construction and Building Materials, vol. 21, no. 7, pp. 1492-1499, 2007.

[26] H. Yazici, "The effect of silica fume and high-volume Class C fly ash on mechanical properties, chloride penetration and freezethaw resistance of self-compacting concrete," Construction and Building Materials, vol. 22, no. 4, pp. 456-462, 2008.

[27] G. C. Isaia, A. L. G. Gastaldini, and R. Moraes, "Physical and pozzolanic action of mineral additions on the mechanical strength of high performance concrete," Cement and Concrete Composites, vol. 25, no. 1, pp. 69-76, 2003.

[28] W. Tangchirapat and C. Jaturapitakkul, "Strength, drying shrinkage, and water permeability of concrete incorporating ground palm oil fuel ash," Cement and Concrete Composites, vol. 32, no. 10, pp. 767-774, 2010.

[29] W. Tangchirapat, C. Jaturapitakkul, and K. Kiattikomol, "Compressive strength and expansion of blended cement mortar containing palm oil fuel ash," Journal of Materials in Civil Engineering, vol. 21, no. 8, pp. 426-431, 2009.

[30] A. R. Boa and L. B. Topu, "Influence of fly ash on corrosion resistance and chloride ion permeability of concrete," Construction and Building Materials, vol. 31, pp. 258-264, 2012.
[31] Q. Yuan, C. Shi, G. de Schutter, K. Audenaert, and D. Deng, "Chloride binding of cement-based materials subjected to external chloride environment-a review," Construction and Building Materials, vol. 23, no. 1, pp. 1-13, 2009.

[32] N. M. Altwair, M. A. M. Johari, and S. F. S. Hashim, "Influence of treated palm oil fuel ash on compressive properties and chloride resistance of engineered cementitious composites," Materials and Structures, pp. 1-16, 2013.

[33] O. Sengul and M. Ali Tasdemir, "Compressive strength and rapid chloride permeability of concretes with ground fly ash and slag," Journal of Materials in Civil Engineering, vol. 21, no. 9, pp. 494-501, 2009.

[34] A. A. Ramezanianpour and V. M. Malhotra, "Effect of curing on the compressive strength, resistance to chloride-ion penetration and porosity of concretes incorporating slag, fly ash or silica fume," Cement and Concrete Composites, vol. 17, no. 2, pp. 125133, 1995. 

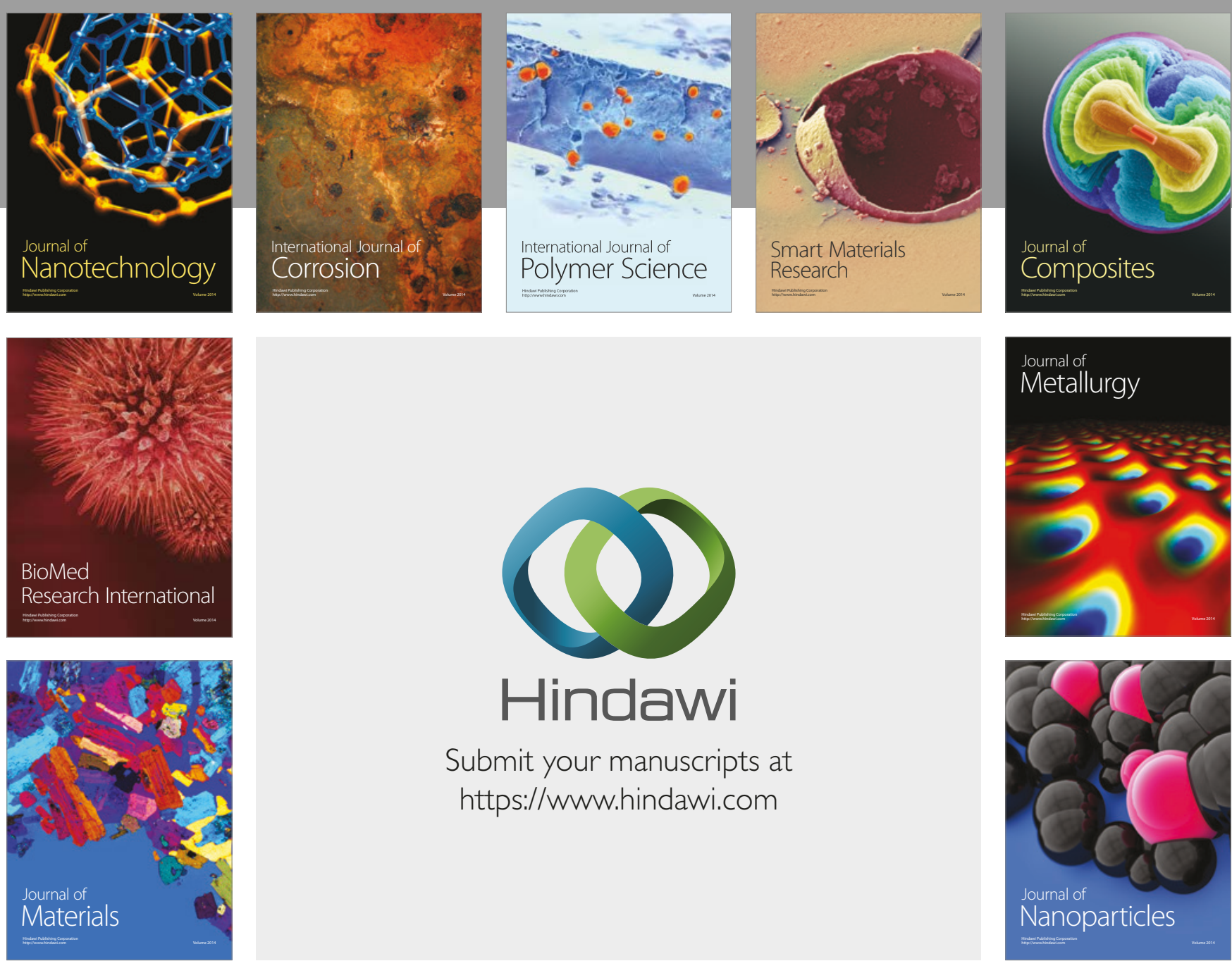

\section{Hindawi}

Submit your manuscripts at

https://www.hindawi.com
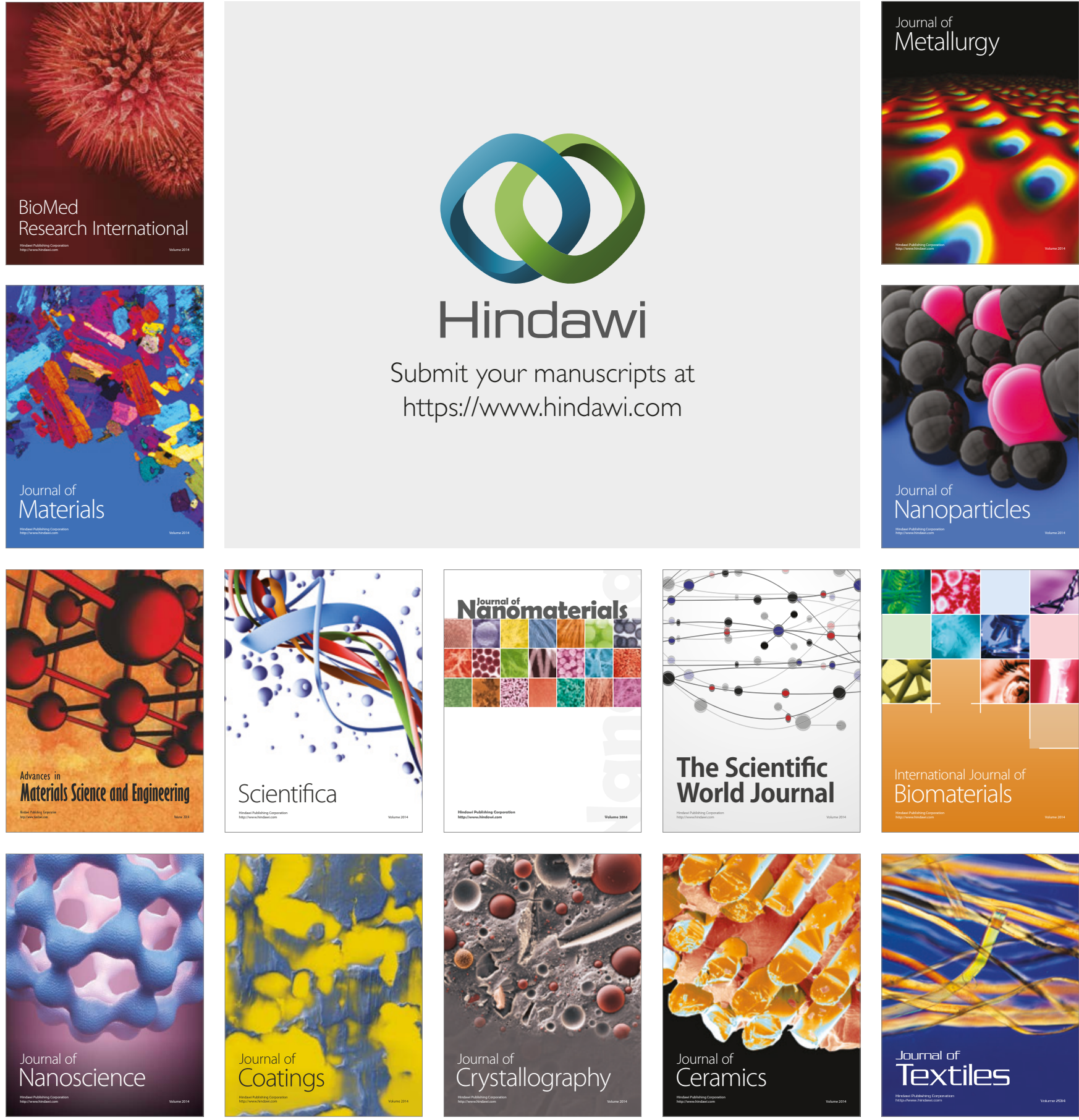



The Scientific World Journal
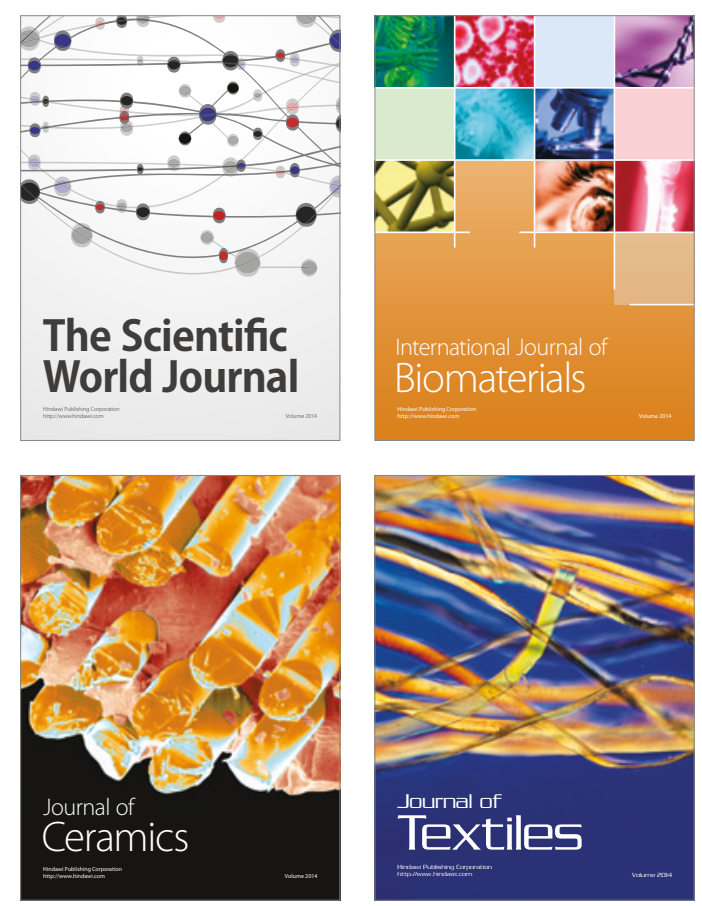